\title{
Evaluasi Strategi Promosi dan Implikasinya Terhadap Penjualan Layanan Internet My Republic
}

\author{
Tri Darmawati ${ }^{1}$, Yasir Arafat ${ }^{2}$ \\ ${ }^{1}$ Manajemen, Fakultas Ekonomi, Univ.PGRI Palembang, tridarmawati@univpgri-palembang.ac.id \\ 2Manajemen, Fakultas Ekonomi, Univ. PGRI Palembang, yasirarafat@univpgri-palembang.ac.id
}

\begin{abstract}
ABSTRAK
My republic adalah salah satu penyedia jasa layanan internet di kota Palembang. Penelitian ini bertujuan untuk mengevaluasi strategi promosi dan implikasinya terhadap penjualan layanan internet my republic di Kota Palembang. Metode yang digunakan analisis kuantitatif dan data yang digunakan data primer dengan melakukan observasi, wawancara, dan kuisioner serta data sekunder berupa data dokumentasi. Populasi dalam penelitian ini adalah konsumen yang menggunakan layanan internet my republic di Kota Palembang khususnya pada kecamatan 9 ilir sebanyak 330 orang. Sampel pada penelitian ini sebanyak 77 orang, dan data yang diperoleh dianalisis menggunakan koefisien korelasi dan regresi linier sederhana sehingga diperoleh hasil $Y=54,244+0,713 X$ dan nilai korelasi $r=0,730$ lebih besar dari $r$ tabel $0,730>0,2242$ yang berarti terdapat hubungan positif dan signifikan antara strategi promosi dengan penjualan layanan internet my republic. Dari hasil uji $t$ di dapat nilai $t_{\text {hitung }}$ lebih besar dari $t_{\text {tabel }} 9,182>1,992$ maka dapat disimpulkan bahwa terdapat pengaruh positif dan signifikan strategi promosi terhadap penjualan layanan internet my republic di Kota Palembang.
\end{abstract}

Kata Kunci : Strategi, Promosi, Penjualan, layanan internet, masyarakat

\section{A. Pendahuluan}

Perkembangan dan perubahan yang cepat pada komunikasi, didorong oleh adanya berbagai penemuan dibidang teknologi. Sehingga apa yang dulu merupakan kendala dalam berkomunikasi sekarang sudah dapat diatasi dengan adanya kemajuan teknologi (Zamroni, 2009). Perkembangan teknologi yang demikian pesat saat ini, telah membawa dampak pada kehidupan masyarakat. Sehingga saat ini masyarakat semakin dimudahkan untuk berkomunikasi. Salah satunya perkembangan komunikasi melalui layanan internet yang serba cepat untuk memenuhi kebutuhan masyarakat. Fenomena ini didukung oleh dunia usaha yang mengalami perkembangan yang sangat pesat dengan munculnya berbagai perusahaan yang berusaha menyediakan layanan internet, guna memenuhi kebutuhan dan keinginan masyarakat. Selain itu perkembangan pesat dalam dunia usaha juga memberikan gambaran tentang kesejahteraan masyarakat yang semakin meningkat. Kesejahteraan yang semakin meningkat ini akan meningkatkan pula daya beli masyarakat. Tetapi, pada sisi lain perkembangan itu menyebabkan timbulnya persaingan yang semakin ketat pada dunia usaha. Perusahaan yang pada mulanya memiliki pangsa pasar yang besar, serta daerah pemasaran yang luas, kini dituntut untuk bekerja lebih efesien dan efektif serta cepat tanggap dalam mengantisipasi pasar yang akan mereka masuki baik pada saat ini maupun yang akan datang.

Salah satu persoalan yang cukup penting dalam suatu perusahaan adalah aspek pemasaran, yaitu bagaimana supaya barang atau jasa 
dapat terjual dan memberikan kepuasan kepada konsumen. Setiap perusahaan akan menganut sistem pemasaran yang berbeda-beda tergantung dari kebutuhan dan besar kecilnya perusahaan. Pelanggan yang mendapatkan promosi yang tepat, meyakinkan dan berkualitas, maka pelanggan akan merasa puas jika hasil evaluasi mereka menunjukkan bahwa produk yang dipakai berkualitas (Mongi, Mananeke, \& Repi, 2013). Untuk itu salah satu faktor penentu keberhasilan penjualan adalah strategi promosi yang tepat, meyakinkan, berulang dan berkualitas untuk meyakinkan masyarakat agar menggunakan produk tersebut. Hal ini didukung juga oleh pernyataan (Rangkuti, 2009) bahwa tantangan terbesar dalam menyusun strategi promosi yang kreatif adalah menentukan strategi promosi mana yang paling efektif. Di era persaingan global saat ini, perusahaan harus dapat menentukan strategi promosi yang tepat sehingga dapat membangun merek dan menjaga hubungan jangka panjang dengan pelanggan. Selain itu meningkatkan penjualan dengan cara merebut market shares dengan tujuan akhir dapat meningkatkan profit. Hal ini tidaklah mudah untuk dilakukan oleh manajemen perusahaan, oleh karena itu harus didukung oleh semua stakeholder yang ada.

(Haryanto, 2013) mengatakan strategi promosi adalah arus informasi atau persuasi satu arah yang dibuat untuk mengarahkan seseorang atau organisasi kepada tindakan yang menciptakan pertukaran dalam pemasaran. Sedangkan (Rangkuti, 2009) menyatakan strategi promosi berkaitan dengan teknik-teknik menyampaikan informasi mengenai produk. Beberapa alat promosi atau lebih dikenal dengan nama bauran promosi, yaitu 1) periklanan dengan menggunakan berbagai media baik cetak maupun elektronik; 2) promosi penjualan dengan cara potongan harga, pemberian kupon; 3) publisitas, yaitu segala sesuatu bentuk komunikasi nonpersonal yang tidak berbayar dan berbentuk gagasan, barang dan jasa dalam bentuk pameran, bakti sosial dan giat lainnya; 4) penjualan personal yaitu presentasi pribadi oleh pramuniaga dengan tujuan melakukan penjualan; 5) pemasaran langsung yaitu hubungan langsung dengan konsumen yang ditargetkan secara seksama untuk meraih respon dan membangun hubungan yang baik dengan pelanggan; 6) media interaktif menggunakan pemasaran online.

(Morissan,

2010)

mendefinisikan bahwa promosi sebagai koordinasi dari seluruh upaya yang dimulai pihak penjual dalam membangun dan memperkenalkan suatu gagasan melalui berbagai saluran informasi dan persuasi untuk menjual barang dan jasa. Selain itu menurut (Suherman, 2010) promosi adalah proses komunikasi yang berisi penyampaian data dan informasi, manfaat serta keunggulan suatu produk kepada khalayak atau masyarakat luas oleh petugas promosi dengan tujuan untuk menarik perhatian sasaran promosi agar menjadi konsumen produk yang dipromosikan. Sedangkan (Mursid, 2006) menyatakan promosi adalah komunikasi yang persuasif, mengajak, menyakinkan. Ciri dari komunikasi yang persuasive adalah ada komunikator yang secara terencana mengatur berita dan cara penyampaianya untuk mendapatkan akibat tertentu dalam sikap dan tingkah laku si penerima. Berdasarkan beberapa teori diatas dapat disimpulkan bahwa promosi merupakan suatu upaya yang 
dilakukan penjual berupa proses komunikasi yang persuasif, mengajak dan meyakinkan untuk menyampaikan informasi, manfaat, serta keunggulan produk melalui berbagai macam saluran informasi kepada masyarakat dengan tujuan agar menjadi konsumen produk yang dipromosikan.

Efektivitas promosi tergantung dari pemilihan strategi promosi yang diperlukan terhadap produk yang dipasarkan. Suatu jenis produk tertentu memerlukan bentuk promosi tertentu pula dan jenis promosi yang lain harus dipergunakan bentuk promosi yang lain pula. Dengan kata lain tidak semua bentuk promosi cocok dan menjamin keberhasilan promosi suatu barang dan jasa. Tentunya harus disesuaikan dengan kondisi yang dimiliki oleh suatu produk yang akan dipromosikan. Demikian halnya dengan layanan internet my republic di Kota Palembang, sebagai salah satu pemain baru dalam hal pemasaran layanan internet yang bergerak dalam jasa telekomunikasi tentunya berusaha untuk melakukan penetrasi pasar untuk mengenalkan dan meningkatkan market shares serta mempertahankan pangsa pasarnya. Penulis mengamati bahwa, layanan internet my republic telah melakukan 6 macam bauran promosi sebagai strategi promosi yang telah dilakukan kepada masyarakat Kota Palembang. Dengan strategi promosi tersebut diharapkan produk yang dihasilkan akan dikenal oleh masyarakat luas dan membangun merek yang kuat serta memiliki identitas yang dapat menggambarkan suatu minat dalam benak konsumen. Serta dapat menarik minat beli konsumen atau calon pembeli sehingga tercapai tujuan perusahaan yaitu meningkatkan penjualan, serta menjadikanya posisi leader di pasar. Walaupun strategi promosi yang dilakukan perusahaan yang terkadang menghabiskan biaya sangat besar, namun tujuan perusahaan melakukan promosi adalah untuk meningkatkan penjualan produk. Terlebih perusahaan yang menghadapi masalah dengan belum dikenalnya merek layanan internet ini di kalangan masyarakat oleh karena itu perusahaan melakukan promosi dengan harapan target penjualan dapat tercapai atau dapat melebihi dari target yang diharapkan.

(Mursid, 2006) mengatakan penjualan merupakan salah satu kegiatan dalam pemasaran, untuk memperoleh peningkatan pertukaran barang atau jasa dengan uang dari waktu ke waktu dalam periode tertentu. Sedangkan menurut (Rachmawati, 2011) penjualan merupakan sumber hidup suatu perusahaan, karena dari penjualan dapat diperoleh laba serta suatu usaha memikat konsumen yang diusahakan untuk mengetahui daya tarik mereka sehingga dapat mengetahui hasil produk yang dihasilkan. Beberapa faktor penentu keberhasilan penjualan antara lain harga produk, kualitas produk, dan pelayanan terhadap konsumen. Dari beberapa teori tersebut dapat disimpulkan penjualan merupakan suatu proses kegiatan pemasaran berupa pertukaran barang atau jasa dengan uang dari hasil usaha penjual dalam membujuk konsumen.

Menurut (Swastha, 2001) sukses bisa dicapai bilamana seseorang itu memiliki suatu tujuan atau cita-cita, demikian pula halnya dengan para pengusaha atau penjual. Tujuan tersebut akan menjadi kenyataan apabila dilaksanakan dengan kemauan dan kemampuan yang memadai. Pada umumnya para pengusaha mempunyai tujuan mendapatkan laba tertentu, dan mempertahankan atau bahkan berusaha meningkatkannya untuk jangka waktu lama. Tujuan tersebut 
dapat dicapai apabila penjualan dapat dilaksanakan seperti

yang direncanakan. Umumnya penjualan mempunyai tujuan 1) mencapai volume penjualan tertentu; 2) mendapatkan laba tertentu; 3) menunjang pertumbuhan perusahaan. Usaha-usaha untuk mencapai ketiga tujuan tersebut tidak sepenuhnya hanya dilakukan oleh pelaksana penjualan atau para penjual. Dalam hal ini perlu adanya kerjasama yang rapi diantara fungsionaris dalam perusahaan (seperti bagian produksi yang membuat produknya, bagian keuangan yang menyediakan dananya, bagian personalia yang menyediakan tenaganya, bagian promosi, dan sebagainya) maupun dengan para penyalur. Namun demikian semua ini tetap menjadi tanggungjawab dari pimpinan.

\section{B. Metode Penelitian}

Penelitian ini menggunakan metode penelitian kuantitatif. Menurut (Sujarweni, 2015) menjelaskan bahwa penelitian kuantitatif merupakan jenis penelitian yang menghasilkan penemuan-penemuan yang dapat diperoleh dengan menggunakan prosedur-prosedur statistik atau caracara lain kuantifikasi. Teknik pengumpulan data yang dilakukan peneliti untuk mengungkap atau menjaring informasi kuantitatif dari responden sesuai lingkup penelitian menggunakan wawancara, kuisioner atau angket, analisis dokumen. Sehingga sumber data yang digunakan adalah sumber data primer dan sekunder.

\section{Tabel 1}

\section{Definisi Operasional Variabel}

\begin{tabular}{|c|c|c|c|c|}
\hline No & Variabel & Definisi Operasional & Indikator & Pernyataan \\
\hline 1 & $\begin{array}{l}\text { Strategi } \\
\text { Promosi } \\
(\mathrm{X})\end{array}$ & $\begin{array}{lr}\text { Promosi merupakan suatu } & \text { menjual } \\
\text { upaya yang dilakukan penjual } & \text { proses komunikasi } \\
\text { berupa proses } & \text { untuk } \\
\text { yang persuasif, mengajak dan } \\
\text { meyakinkan } \\
\text { menyampaikan informasi, } \\
\text { manfaat, serta keunggulan } \\
\text { produk melalui berbagai } \\
\text { macam saluran informasi } \\
\text { kepada masyarakat dengan } \\
\text { tujuan agar menjadi konsumen } \\
\text { produk yang dipromosikan. }\end{array}$ & $\begin{array}{l}\text { 1. Periklanan } \\
\text { 2. Promosi } \\
\text { Penjualan } \\
\text { 3. Publisitas } \\
\text { 4. Penjualan } \\
\text { Personal } \\
\text { 5. Pemasaran } \\
\text { Langsung } \\
\text { 6. Media } \\
\text { Interaktif }\end{array}$ & $\begin{array}{l}1,2 \\
3,4 \\
5,6 \\
7,8 \\
9,10 \\
11,12\end{array}$ \\
\hline 2 & $\begin{array}{l}\text { Penjualan } \\
(\mathrm{Y})\end{array}$ & $\begin{array}{l}\text { penjualan merupakan suatu } \\
\text { proses kegiatan pemasaran } \\
\text { berupa pertukaran barang atau } \\
\text { jasa dengan uang dari hasil } \\
\text { usaha penjual dalam } \\
\text { membujuk konsumen. }\end{array}$ & $\begin{array}{ll}\text { 1. Harga Produk } \\
\text { 2. Kualitas } \\
\text { produk } \\
\text { 3. Pelayanan } \\
\text { terhadap } \\
\text { konsumen }\end{array}$ & $\begin{array}{l}1,2,3,4 \\
5,6,7,8 \\
9,10,11,12\end{array}$ \\
\hline
\end{tabular}

Menurut (Sugiyono, 2010) populasi adalah sejumlah anggota yang terdiri atas obyek atau subjek yang mempunyai kualitas dan karakteristik tertentu yang ditetapkan oleh peneliti untuk dipelajari dan kemudian ditarik kesimpulannya. Sehubungan keterbatasan biaya dan 
waktu maka peneliti mengambil populasi sebanyak 330 konsumen. Menurut (Sujarweni, 2015) sampel adalah sebagian dari sejumlah karakteristik yang dimiliki oleh populasi yang digunakan untuk penelitian. Besar sampel yang digunakan didasarkan pada pendapat slovin, yaitu sebagai berikut:

\section{Dimana:}

$$
n=\frac{N}{1+\left(N \cdot e^{2}\right)}
$$

$$
\begin{array}{ll}
\mathrm{n} & =\text { Jumlah Sampel } \\
\mathrm{N} & =\text { Jumlah Populasi }=330 \text { responden } \\
e^{2} & =\text { Presesi ditetapkan } 10 \%
\end{array}
$$

Berdasarkan rumus tersebut diperoleh jumlah sampel sebagai berikut:

$$
n=\frac{N}{1+\left(N \cdot e^{2}\right)}=\frac{330}{1+\left(330 \times 0,1^{2}\right)}=\frac{330}{4,3}=76,7
$$

Dari perhitungan diatas dapat ditarik kesimpulan bahwa sampel sudah dapat mewakili responden (dapat dilakukan penelitian). Pada penelitian ini sampel yang diambil sebanyak 77 responden. Teknik penarikan sampel yang dipakai adalah Random Sampling artinya teknik penentuan sampel diambil dengan cara acak yaitu, konsumen yang menggunakan produk layanan internet my republic di Kota Palembang. Ketepatan pengujian suatu hipotesa tentang hubungan variabel penelitian sangat bergantung pada kualitas data yang dipakai dalam pengujian tersebut. Pengumpulan data dilakukan dengan menggunakan kuesioner sehingga keabsahan dan keaslian suatu hasil penelitian sangat ditentukan oleh alat ukur yang digunakan, dimana apabila alat ukur yang digunakan tidak valid atau tidak dapat dipercaya maka hasil penelitian yang diperoleh tidak akan menggambarkan kebenaran yang sesungguhnya. Untuk menguji kesahihan dan keandalan kuesioner ini, maka dilakukan pengujian validitas dan reliabilitas dengan menggunakan program SPSS versi 22.

Menurut (Sujarweni, 2015) uji validitas digunakan untuk mengukur sah atau valid tidaknya suatu kuisioner. Pengujian validitas, dilakukan dengan cara menguji instrumen penelitian berupa kuisioner dengan menghitung koefesien korelasi antara skor item dan skor totalnya dalam taraf signifikasi 0.05 dengan rumus korelasi product moment pearson. Instrumen penelitian bisa dikatakan valid apabila mempunyai nilai $r_{\text {hitung }}>r_{\text {tabel }}$ dengan tingkat signifikansi korelasi di bawah $\alpha=0.05$. Dan apabila $r_{\text {hitung }}<r_{\text {tabel }}$, artinya pernyataan atau indikator tersebut tidak valid.

Rumusnya sebagai berikut:

$$
r=\frac{n \sum X i Y-\left(\sum X_{i}\right)\left(\sum Y_{i}\right)}{\left.\sqrt{\left\{n \sum X^{2}\right.}-\left(\sum X\right)^{2}\right\}\left\{n \sum Y^{2}-\left(\sum Y\right)^{2}\right\}}
$$

Dimana :

$$
\begin{array}{ll}
\mathrm{R} & =\text { koefisien korelasi } \\
\mathrm{n} & =\text { banyaknya sampel } \\
\Sigma \mathrm{X} & =\text { jumlah skor item } \mathrm{X} \\
\Sigma \mathrm{Y} & =\text { jumlah skor item } \mathrm{y}
\end{array}
$$

Uji validitas strategi promosi (X) dengan menggunakan SPSS 22 for windows yaitu dengan hasil sebagai berikut

Tabel 2

Data Hasil Uji Validitas Promosi

\begin{tabular}{|c|c|c|c|c|}
\hline No & Pernyataan & $\boldsymbol{r}_{\text {tabel }}$ & $\boldsymbol{r}_{\text {hitung }}$ & Keterangan \\
\hline 1 & Pernyataan 1 & 0,361 & 0,667 & Valid \\
\hline 2 & Pernyataan 2 & 0,361 & 0,514 & Valid \\
\hline 3 & Pernyataan 3 & 0,361 & 0,610 & Valid \\
\hline 4 & Pernyataan 4 & 0,361 & 0,653 & Valid \\
\hline
\end{tabular}




\begin{tabular}{|c|c|c|c|c|}
\hline 5 & Pernyataan 5 & 0,361 & 0,659 & Valid \\
\hline 6 & Pernyataan 6 & 0,361 & 0,654 & Valid \\
\hline 7 & Pernyataan 7 & 0,361 & 0,555 & Valid \\
\hline 8 & Pernyataan 8 & 0,361 & 0,669 & Valid \\
\hline 9 & Pernyataan 9 & 0,361 & 0,588 & Valid \\
\hline 10 & Pernyataan 10 & 0,361 & 0,490 & Valid \\
\hline 11 & Pernyataan 11 & 0,361 & 0,382 & Valid \\
\hline 12 & Pernyataan 12 & 0,361 & 0,456 & Valid \\
\hline
\end{tabular}

Dari hasil pengolahan data menggunakan SPSS 22 for windows menunjukan bahwa hasil uji validitas dari 12 item pertanyaan pada variabel promosi mendapatkan hasil keseluruhan valid. Dengan demikian keseluruhan item pertanyaan yang ada pada instrument tersebut dapat dijadikan sebagai alat ukur yang valid dalam analisis selanjutnya. Selanjutnya uji validitas penjualan (Y) dengan menggunakan SPSS 22 for windows yaitu dengan hasil sebagai berikut:

Tabel 3

Data Hasil Uji Validitas Penjualan

\begin{tabular}{|c|c|c|c|c|}
\hline No & Item Pertanyaan & $\boldsymbol{r}_{\text {tabel }}$ & $\boldsymbol{r}_{\text {hitung }}$ & Keterangan \\
\hline 1 & Pernyataan 1 & 0,361 & 0,503 & Valid \\
\hline 2 & Pernyataan 2 & 0,361 & 0,571 & Valid \\
\hline 3 & Pernyataan 3 & 0,361 & 0,570 & Valid \\
\hline 4 & Pernyataan 4 & 0,361 & 0,634 & Valid \\
\hline 5 & Pernyataan 5 & 0,361 & 0,514 & Valid \\
\hline 6 & Pernyataan 6 & 0,361 & 0,501 & Valid \\
\hline 7 & Pernyataan 7 & 0,361 & 0,390 & Valid \\
\hline 8 & Pernyataan 8 & 0,361 & 0,410 & Valid \\
\hline 9 & Pernyataan 9 & 0,361 & 0,380 & Valid \\
\hline 10 & Pernyataan 10 & 0,361 & 0,475 & Valid \\
\hline 11 & Pernyataan 11 & 0,361 & 0,482 & Valid \\
\hline 12 & Pernyataan 12 & 0,361 & 0,556 & Valid \\
\hline
\end{tabular}

Dari hasil pengolahan data menggunakan SPSS 22 for windows menunjukan bahwa hasil uji validitas dari 12 item pertanyaan pada variabel penjualan $Y$ keseluruhan valid. Dengan demikian keseluruhan item pertanyaan yang ada pada instrumen tersebut dapat dijadikan sebagai alat ukur yang valid dalam analisis selanjutnya. Langkah selanjutnya dilakuan uji reliabilitas. (Sujarweni, 2015) mengatakan uji reliabilitas merupakan ukuran suatu kestabilan dan konsistensi responden dalam menjawab hal yang berkaitan dengan kontruk-konstruk pertanyaan yang merupakan dimensi suatu variabel dan disusun dalam suatu bentuk kuisioner. Untuk menghitung reliabilitas seluruh instrumen dilakukan dengan rumus Spearman Brown.

$$
r_{i}=\frac{2 r_{b}}{1+r_{b}}
$$

Dimana :

$r_{i} \quad=$ Koefisien reabilitas

$r_{b} \quad=$ Koefisien korelasi skor butir dengan skor total 
Uji reliabilitas merupakan suatu instrumen yang dapat dipercaya untuk digunakan sebagai alat pengumpul data karena instrumen tersebut sudah baik. Butir pernyatan dikatakan reliabel apabila jawaban seseorang terhadap pertanyaan adalah konsisten. Pengukuran reliabilitas dilakukan dengan cara one shot atau pengukuran sekali saja. Pengukuran butiran pertanyaan dengan sekali menyebarkan kuisioner pada responden, kemudian hasil skornya diukur korelasinya antar skor jawaban pada butir pertanyaan yang sama dengan bantuan SPPS versi 22. Suatu konstruk atau variabel dikatakan reliabel jika memberikan nilai cronbech alpha > 0,06. Hasil uji reliabilitas variabel promosi dengan menggunakan SPSS 22 for windows yaitu dengan hasil sebagai berikut.

Tabel 4

Reliabilitas Promosi

Reliability Statistics

\begin{tabular}{|r|r|}
\hline Cronbach's Alpha & N of Items \\
\hline, 786 & 12 \\
\hline
\end{tabular}

Hasil uji relibilitas di dapat dari nilai cronbach alpha sebesar 0,786 >0.06. karena nilai diatas 0,06 maka dapat disimpulkan bahwa alat ukur strategi promosi dalam penelitian ini reliabel dan dapat dijadikan alat ukur analisis selanjutnya. Selanjutnya Hasil uji reliabilitas variabel penjualan $Y$ dengan menggunakan SPSS 22 for windows yaitu dengan hasil sebagai berikut:

Tabel 5

Reliabilitas Penjualan

Reliability Statistics

\begin{tabular}{|r|r|}
\hline Cronbach's Alpha & N of Items \\
\hline, 891 & 12 \\
\hline
\end{tabular}

Hasil uji relibilitas di dapat dari nilai cronbach alpha sebesar 0,891> 0.06 . karena nilai diatas 0,06 maka dapat disimpulkan bahwa alat ukur dalam penelitian ini reliabel dan dapat dijadikan alat ukur analisis selanjutnya.

\section{Pembahasan}

Berdasarkan data di atas, penulis akan mencari pengaruh antara variabel $X$ dan variabel $Y$ dengan menggunakan program SPSS versi 22. Analisis regresi linier sederhana digunakan untuk mengetahui pengaruh atau hubungan secara linier antara satu variabel independen dengan variabel dependen. Menurut Sugiyono
(2010:270), regresi sederhana didasarkan pada hubungan fungsional ataupun kausal satu variabel independen dengan satu variabel dependen. Analisis regresi ini bertujuan untuk mengetahui seberapa besar pengaruh variabel $X$ (promosi) terhadap $Y$ (penjualan). Sedangkan untuk mencari nilai a dan b digunakan rumus sebagai berikut:

$$
\begin{aligned}
& a=\frac{\left(\sum y_{i}\right)\left(\sum X_{i}^{2}\right)-\left(\sum X_{i}\right)\left(\sum\left(X_{i} Y_{i}\right)\right.}{n \cdot\left(\sum X_{i}^{2}\right)-\left(\sum X_{i}\right)^{2}} \\
& b=\frac{n\left(\sum X_{i} Y_{i}\right)-\left(\sum X_{i}\right)\left(\sum Y_{i}\right)}{n \sum X_{i}^{2}-\left(\sum X_{i}\right)^{2}}
\end{aligned}
$$


Keterangan:

$Y^{\prime}=$ subyek dalam variabel dependen yang diprediksikan.

$\mathrm{a}=$ bilangan konstanta

$$
\begin{aligned}
& \mathrm{b}=\text { koefisien variabel } \mathrm{X} \\
& \mathrm{X}=\text { subyek pada variabel independen } \\
& \quad \text { yang mempunyai nilai tertent } \mathrm{C} \text {. }
\end{aligned}
$$

\section{Tabel 6 \\ Regresi Linier Sederhana

\begin{tabular}{|c|c|c|c|c|c|}
\hline \multirow[b]{2}{*}{ Model } & \multicolumn{2}{|c|}{$\begin{array}{l}\text { Unstandardized } \\
\text { Coefficients }\end{array}$} & \multirow{2}{*}{\begin{tabular}{|c|}
$\begin{array}{c}\text { Standardized } \\
\text { Coefficients }\end{array}$ \\
Beta \\
\end{tabular}} & \multirow[b]{2}{*}{$t$} & \multirow[b]{2}{*}{ Sig. } \\
\hline & $\mathrm{B}$ & Std. Error & & & \\
\hline $\begin{array}{ll}1 & \text { (Constant) } \\
& \text { Strategi promosi }\end{array}$ & $\begin{array}{r}54,244 \\
.713\end{array}$ & $\begin{array}{r}2,351 \\
.072\end{array}$ & 620 & $\begin{array}{l}6,866 \\
9,182\end{array}$ & $\begin{array}{l}.000 \\
.000\end{array}$ \\
\hline
\end{tabular} \\ Strategi Promosi Terhadap Penjualan \\ Coefficients $^{a}$}

a. Dependent Variable: penjualan

Setelah nilai a dan b ditemukan, maka persamaan regresi linear sederhana yang didapat adalah sebagai berikut:

$\mathrm{Y}=54,244+0,713 \mathrm{X}$

Berdasarkan perhitungan persamaan regresi linear sederhana diatas diperoleh nilai konstanta atau a adalah 54,244, dan nilai koefisien regresi atau $b$ adalah 0,713 . Nilai konstanta sebesar 54,244 menunjukan bahwa apabila nilai promosi 0 satuan maka nilai penjualan sebesar 54,244. Nilai regresi 0,713 menunjukan bahwa apabila nilai strategi promosi naik satu satuan maka nilai penjualan akan bertambah sebesar 0,713.

Selanjutnya dilakukan analisis korelasi antara variabel-variabel tersebut. Menurut (Sugiyono, 2010), analisis korelasi adalah teknik kuantitatif yang digunakan untuk mengukur keeratan hubungan atau korelasi antara dua variabel atau lebih. Maka persamaan yang dapat digunakan untuk menghitung koefesien korelasi adalah sebagai berikut:

$$
r=\frac{n\left(\sum x y\right)-\left(\sum x\right)\left(\sum y\right)}{\sqrt{\left\lfloor n\left(\sum X^{2}\right)-\left(\sum X\right)^{2}\right\rfloor\left\lfloor n\left(Y^{2}\right)-\left(\sum Y\right)^{2}\right\rfloor}}
$$

Dimana :

$$
\begin{array}{rlrl}
r & = & \text { Nilai koefisien korelasi } \\
\mathrm{X} & = & \text { Nilai variabel bebas yaitu } \\
& \text { strategi promosi } \\
\mathrm{Y} & =\text { Nilai variabel terikat yaitu penjualan }
\end{array}
$$

Untuk melihat kuat tidaknya hubungan antara dua variabel tersebut dapat dicari dengan menggunakan SPSS versi 22 sebagai berikut:

\section{Tabel 7}

\section{Koefisien Korelasi}

Model Summary

\begin{tabular}{|l|r|r|r|r|}
\hline $\begin{array}{l}\text { Mode } \\
\mathrm{l}\end{array}$ & $\mathrm{R}$ & $\begin{array}{c}\mathrm{R} \\
\text { Square }\end{array}$ & $\begin{array}{c}\text { Adjusted R } \\
\text { Square }\end{array}$ & $\begin{array}{c}\text { Std. Error of } \\
\text { the Estimate }\end{array}$ \\
\hline 1 &, $730^{\mathrm{a}}$ &, 5329 &, 378 & 2,429 \\
\hline
\end{tabular}

a. Predictors: (Constant), strategi promosi

Untuk dapat memberikan penafsiran terhadap koefisien korelasi yang ditemukan tersebut besar atau kecil, maka dapat berpedoman pada ketentuan yang tertera pada tabel 6 sebagai berikut (Sugiyono, 2010): 


Tabel 8
\begin{tabular}{|c|c|} 
Interpretasi Koefisien Korelasi \\
\hline $\begin{array}{c}\text { Interval } \\
\text { Koefisien }\end{array}$ & Tingkat Hubungan \\
\hline $0,00-0,199$ & Sangat Rendah \\
\hline $0,20-0,399$ & Rendah \\
\hline $0,40-0,599$ & Sedang \\
\hline $0,60-0,799$ & Kuat \\
\hline $0,80-1,000$ & Sangat Kuat \\
\hline
\end{tabular}

Berdasarkan hasil perhitungan nilai koefisien korelasi $(r)$ diatas dapat diketahui nilai $r=0,730$ yang berarti bahwa hubungan antara strategi promosi dengan penjualan layanan internet my republic di Kota Palembang adalah kuat. Koefisien determinasi digunakan untuk mengetahui uraian yang dapat diterangkan oleh persamaan regresi yaitu untuk mengetahui seberapa besar variabel yang dapat di terangkan oleh variabel $\mathrm{X}$.

$$
R=\left(r^{2}\right) \times 100
$$

Dimana:

$\begin{array}{ll}\text { R } & \text { : Koefisien determinasi } \\ r & : \text { Koefisien korelasi }\end{array}$

Tabel 9
$\begin{gathered}\text { Toefisien Determinasi } \\
\text { Kodel Summary } \\
\text { Moder }\end{gathered}$
\begin{tabular}{|l|l|r|r|r|r|}
\hline Model & $\mathrm{R}$ & $\mathrm{R}$ Square & Adjusted R Square & Std. Error of the Estimate \\
\hline 1 &, $730^{\mathrm{a}}$ &, 5329 &, 378 & 2,429 \\
\hline
\end{tabular}

a. Predictors: (Constant), strategi promosi

\begin{tabular}{lcr}
\multicolumn{2}{c}{ Koefisien } & determinasi \\
digunakan & untuk & mengetahui \\
presentase & sumbangan & variabel \\
independen & terhadap & variabel \\
dependen. & Berdasarkan tabel & diatas \\
diperoleh & koefisien & determinasi \\
sebesar & 0,5329 atau & $53,29 \%$ \\
sedangkan & sisanya & $46,71 \%$ \\
dipengaruhi & oleh variabel lain yang \\
tidak diteliti pada penelitian ini. Setelah \\
diperoleh hasil perhitungan regresi \\
linier sederhana, koefisien korelasi dan \\
kooefisien determinasi antara strategi \\
promosi dan penjualan, maka \\
dilakukan uji hipotesis. Menurut \\
Sugiyono & (2014:93), uji hipotesis \\
merupakan jawaban & sementara \\
terhadap rumusan masalah penelitian,
\end{tabular}

oleh karena itu rumusan masalah penelitian biasanya disusun dalam bentuk kalimat pertanyaan. Uji hipotesis juga dapat dihitung dengan menggunakan rumus $U j \mathrm{ji}$ sebagai berikut:

$$
\begin{aligned}
& T_{\text {Hitung }}=\frac{r \sqrt{(n-2)}}{\sqrt{\left(1-r^{2}\right)}} \\
& \text { Dimana: } \\
& \begin{array}{ll}
T_{\text {hitung }} & =\text { Nilai } \mathrm{t} \\
\mathrm{r} & =\text { Nilai koefisien korelasi } \\
\mathrm{n} \quad & =\text { jumlah data }
\end{array}
\end{aligned}
$$

Untuk menghitung nilai $t$ dilakukan menggunakan SPSS versi 22 for windows. dengan hasil sebagai berikut: 


\section{Tabel 10 \\ Uji t}

Coefficients $^{a}$

\begin{tabular}{|ll|r|r|c|r|r|}
\hline \multirow{2}{*}{ Model } & \multicolumn{2}{|c|}{$\begin{array}{c}\text { Unstandardized } \\
\text { Coefficients }\end{array}$} & \multicolumn{2}{c|}{$\begin{array}{c}\text { Standardized } \\
\text { Coefficients }\end{array}$} & & \multirow{2}{*}{. } \\
\cline { 2 - 5 } & \multicolumn{1}{|c|}{$\mathrm{B}$} & Std. Error & Beta & \multicolumn{1}{c|}{ Sig. } \\
\hline (Constant) & 54,244 & 2,351 & & 6,866 &, 000 \\
& Strategi promosi &, 713 &, 072 &, 620 & 9,182 &, 000 \\
\hline
\end{tabular}

a. Dependent Variable: penjualan

Berdasarkan hipotesis yang sudah dikemukakan sebelumnya, bahwa terdapat pengaruh positif dan signifikan strategi promosi terhadap penjualan layanan internet my republic di Kota Palembang. Hal ini bisa dilihat dari nilai signifikansi $<0,05$ dan nilai $t_{\text {hitung }}>t_{\text {tabel }}$. Selanjutnya nilai $t_{\text {hitung }}=9,182$ tersebut dibandingkan dengan $t_{\text {tabel }}$ dengan taraf nyata 0,05 , $\mathrm{dk}=\mathrm{n}-2$ jadi $\mathrm{dk}=77-2=75$, nilai $\mathrm{dk} 75$ pada nilai distribusi $t_{\text {tabel }}$ yaitu $=$ 1,992. Dengan demikian nilai t hitung lebih besar dari t tabel $(9,182>1,992)$ sehingga dapat ditarik kesimpulan terdapat pengaruh positif dan signifikan strategi promosi terhadap penjualan layanan internet my republic di Kota Palembang.

\section{Kesimpulan}

Berdasarkan hasil penelitian dan pembahasan, maka penulis menarik kesimpulan sebagai berikut: Dengan nilai $Y=54,244+0,713 X$, maka diketahui bahwa terdapat pengaruh positif dan signifikan strategi promosi terhadap penjualan. Semakin intensif strategi promosi dilakukan maka akan semakin meningkatkan penjualan layanan internet my republic. Hasil perhitungan koefesien korelasi, diperoleh nilai $r=0,730$. Karena nilai korelasi sederhana berada antara 0,60 - 0,799. Maka kesimpulannya adalah ada hubungan yang positif dan kuat antara strategi promosi terhadap penjualan layanan internet my republic di Kota Palembang. Dari hasil pengujian hipotesis yang dilakukan dengan menggunakan SPSS 22 maka diperoleh $t_{\text {hitung }}$ yaitu 9,182 sedangkan $t_{\text {tabel }}$ untuk taraf kesalahan 5\% dengan $\mathrm{dk}=75$ maka diperoleh $t_{\text {tabel }} 1,992$. Maka hal ini menunjukan bahwa terdapat pengaruh positif dan signifikan strategi promosi terhadap penjualan layanan internet my republic di Kota Palembang. Untuk meningkatkan penjualan maka perusahaan perlu meningkatkan lagi strategi promosi yang dilakukannya, seperti dari segi periklanan, promosi penjualan, publisitas, penjualan personal, pemasaran langsung dan media interaktif. Selain itu perlu juga dilakukan penelitian lanjutan dengan variabel lain yang dapat meningkatkan penjualan, seperti harga, kualitas pelayanan, produk.

\section{DAFTAR PUSTAKA}

Haryanto, R. A. (2013). Strategi promosi, kualitas produk, kualitas layanan terhadap kepuasan pelanggan pada restoran Mcdonalds Manado. Jurnal $E M B A$, Vol.1 No.4 hal. 14651473.

Mongi, L., Mananeke, L., \& Repi, A. (2013). Kualitas Produk, Strategi Promosi, dan pengaruhnya terhadap Keputusan Pembelian 
Kartu Simpati Telkomsel di Kota Manado. Jurnal Riset Ekonomi, Manajemen, Bisnis, dan Akuntansi, Vol.1 No. 4 Desember 2013, hal. 2336-2346.

Morissan. (2010). Periklanan. Jakarta: Kencana.

Mursid. (2006). Manajemen Pemasaran. Jakarta: Bumi Aksara.

Rachmawati, R. (2011). Peranan Bauran Pemasaran (Marketing Mix) Terhadap Peningkatan Penjualan (Sebuah Kajian Terhadap Bisnis Restoran). Jurnal Kompetensi Teknik, Vol.2 No.2 Hal. 143-150.

Rangkuti, F. (2009). Strategi Promosi Yang Kreatif dan Analisis Kasus Integrated

Marketing
Communication. Jakarta: PT. Gramedia Pustaka Utama.

Sugiyono. (2010). Metode Penelitian Bisnis. Bandung: Alfabeta.

Suherman, E. (2010). Business Entrepreaneur. Bandung: Alfabeta.

Sujarweni, W. (2015). Metode Penelitian Bisnis \& Ekonomi. Yogyakarta: Pustaka Baru Press.

Swastha, B. (2001). Manajemen Penjualan. Yogyakarta: BPFE.

Zamroni, M. (2009). Perkembangan Teknologi Komunikasi dan Dampaknya terhadap Kehidupan. Jurnal Dakwah Media Komunikasi dan Dakwah, Vol.10 No.2 hal.195-211. 